\title{
Advantages of Intervention of Social Work in Targeted Alleviation of Poverty
}

\author{
Dong Xiaoshuang \\ Candidate for Master in Social Sciences \\ School of Political Science and Law, \\ University of Ji'nan, Ji'nan City, P.R.China
}

\author{
Li Zonghua \\ Professor \& Master's Advisor, \\ School of Political Science and Law, \\ University of Ji'nan, Ji’nan City, P.R.China
}

\begin{abstract}
Unlike generalized alleviation, targeted alleviation of poverty refers to the employment of scientific and effective programs to identify and support impoverished population and to manage supportive system in accordance with living condition and background of each household. Social work is an important way of poverty alleviation, and the philosophy and practices associated with social work match well with the principle and duty of targeted alleviation. Social work is advanced with its theory of entitlement, its goal of supporting the disadvantaged people and gaining autonomy, and its principle of individualized services based on needs. Social work is able to pinpoint the needy, empower them, and design solutions for sustainable growth.
\end{abstract}

Keywords-Targeted Alleviation of Poverty; Social Work; Entitlement \&Empowerment

\section{INTRODUCTION}

Over 70 million people are still disadvantaged in China. They are distributed across the whole mainland of China and live in extreme poverty. The country's goal for development towards 2020 includes plans to improve living conditions of the impoverished people. Social work is professional in and capable of cooperation with government departments to offer services to this group.

Social work traces back well to poverty alleviation. It originated from western society as a mission to help poor people, the evolution of social work is a history of human's fights against poverty, and its values have been developed from people's trials to solve social issues.

\section{EMPOWERMENT OF SOCIAL WORKERS ACCORDS WELL WITH TARGETED ALLEVIATION OF POVERTY}

\section{A. Theory of Entitlement \&Empowerment, Targeted Alleviation of Poverty}

In his book Poverty and Famines, Amartya Sen described the 1943 Bengal famine and the 1983 Sudanese famine, and illustrated that decline of food supply was not the root of famine but one of its forms[1]. Prof. Amartya Sen put the issue in the scopes of politics, social sciences, philosophy, economics, and ethics, and viewed starvation and impoverishment in terms of entitlement and empowerment, providing research work on poverty with new tools of analysis. It's a milestone for the theory of poverty.
In Amartya Sen's view, poverty not only refers to a fact but also implies lack of chances or choices caused by living conditions and social environments. Therefore, disentitlement is the real cause of poverty and famine [2].

Specifically, private ownership system in market economy will grant an individual the rights to produce, to labor, and to trade, and allow him to inherit or assign such rights. Such a group of rights ensure freedom of an economic entity to act and earn. Loss or deprival of any of such rights will result in weakened execution on part of the entity. History has shown that loss or deprival of people's titles to their portion of food will result in large-scale poverty or famine[3].

Targeted alleviation of poverty involves accurate identification of and appropriate support to the needy, as well as scientific management and fine evaluation of alleviation efforts. This move underlies the search for roots of poverty and the care for impoverished people. It balances freedom with growth, and weighs fairness with justice. Its principle accords well with Amartya Sen's theory of entitlement and empowerment, a theory that can be taken as the basis for the move because it points out the core of poverty issue. According to this theory, entitlement and empowerment on part of the impoverished people will be the key to poverty alleviation.

\section{AgREEABle CONTENTS}

\section{A. Individualized social work is better for targeted alleviation of poverty}

Unlike generalized poverty alleviation measures, targeted alleviation calls for precise identification of those really in need. Social workers are therefore advised to find out underlying causes of poverty and realize real needs of the impoverished people.

Judging from Amartya Sen's multi-dimensional analysis of issues associated with China's impoverished population, the group's poverty result from poor education, harsh environment and diseases. Although they are deprived of rights and chances for development and therefore are generally eager for improvements and public services, they belong to a variety of regions, groups, and households, and are in diversified needs and show different aptitudes. Ignorance of these facts, reliance purely on figures, or wholesale promotion of empowerment plans, will fail to pinpoint those in real needs and degrade in generalized alleviation of poverty. 
Therefore, targeted alleviation of poverty shall be carried out village by village, household by household, and person by person. Social workers shall take advantage of their "unofficial" titles [4] to carry out baseline investigations and check the results with the government's records to form a database of personal information about the subjects' causes of poverty, personal talents, social backgrounds, and requirements. Thereafter, an individualized plan of empowerment [5] can be formulated for each person listed in the database and be filed with the household, village, country and county that the subject belongs to. Each subject shall be assigned with a social worker to follow up his empowerment plan and intervene when necessary to help the subject to deal with big issues.

In 2001, Hong Kong Polytechnic University and Yunnan University co-operated a model of "Green Stockade" [6]. Success of this project shows initiatives on part of the farmers (the impoverished group) will be excited by baseline investigations and traceable managements of alleviation efforts. In this project, social workers interviewed with villagers to understand their conditions and learn about their needs. Such talks proved to have eliminated psychological barriers between social workers and the villagers. Discussions were then organized in which the villagers are invited to express their views about current issues and their hopes. Later on, community funds were established to support the villagers to carry out production and sales of craftworks and practice coordination, administration and financial management.

\section{B. The philosophy of supporting others and ourselves contributes to sustainable development}

Targeted alleviation of poverty involves not only satisfaction of needs of impoverished farmers but also assessments of their talents and searches for sustainable developments. Social workers may contribute to this mission by the following two ways:

Take advantages and free potentials. The theory of advantageous scope requires a social worker to identify competitiveness on part of the subject. The philosophy of supporting others and ourselves calls for social workers to seek ways of sustainable development for their subjects. Effective social work is firstly reasonable assessment of the subject's needs and identify individual advantages and available resources for the subject. This is the condition for targeted alleviation of poverty.

Link resources and integrate competencies. A social worker shall analyze relations between needs of impoverished people and resources available from suppliers. Multi-dimensional and allocable resources are critical for precise alleviation of poverty [7]. National, corporate, social and local resources can all be counted on as poverty alleviators. Current Social Work prefers individualized management and requires a social worker to organize and coordinate different resources in accordance with individual needs of each subject. Social workers shall be able to take full advantage of experiences [8] with government purchase projects and coordinate government resources to improve their effects on poverty alleviation and realize the most cost-effective identification of impoverished people.

\section{Social workers adhere to fairness and justice to identify impoverished people}

Social justice is the main and fundamental character of modern society and of socialist system, and it's also the pursuit of social workers, who believe social justice shall be realized across ages, genders, careers, and races, and be enjoyed by all people as a result of social progress. Throughout the evolution of social work, justice has been consciously pursued by social workers. Unlike administrative work, social work is valued for its pursuit of justice, and is carried out with professional approaches to empower disadvantaged groups, coordinate social relations, prevent/resolve social issues, and promote social justice. Social work is capable of shaping policies in favor of the disadvantaged groups and in defense of their rights. It is able to redistribute social wealth, reconcile interests, and maintain justice. Social workers care for the disadvantaged groups and seek to intervene with injustice, redress poverty, gratify needs, and protect their rights. The goal of socialism is to eradicate poverty and realize equity, whereas targeted alleviation and relief of poverty is the strategy for realizing the goal.

As Chinese government invested a lot of resources for poverty relief and regional development, several issues emerged in forms of systematic defects, aimless relief measures, poor service quality and low efficiency. It is therefore necessary to refine poverty relief policy and spend limited resources on the most impoverished people. It is also necessary to build a sense of belonging among all people, rid them of poverty, narrow down their income gaps, and promote social justice.

\section{Social workers are able to adopt scientific approaches to relieve poverty}

Social work is supposed to follow certain philosophies, rely on professional approaches, serve disadvantaged groups, coordinate social relations, solve real issues, recover group functions, resume normal development, and promote social welfare. Social work is a discipline because it is based on philosophies and carried out with professional approaches, which include team work, case work and community work. It is also supplemented by case guide, team skills, resource allocation, consulting services, and training sessions. Social work aims to study the situation of impoverished groups and offer differentiated and considerate assistants. Similarly, targeted poverty relief measures seek to classify impoverished groups, count in regional differences, identify poverty causes, and analyze poverty groups. Targeted relief of poverty is an optimal approach to pinpoint the destitute, scheme projects, allocate funds, assist households, assign staffs, and improve effects. The approach is expected to help disadvantaged groups out of poverty by employing them in manufactories, moving them to new regions, protecting their environments, offering educational services, and providing subsistence pensions. Poverty can also be relieved by means of delegated aids, professional trainings, small loans, cross-regional movements, e-commerce activities, tourism developments, PV panel installation, tree plantings, entrepreneurship cultivations, 
and corporation supports. These policies, strategies, approaches and projects are evidence of system and rationality that characterize targeted relief of poverty.

\section{EFFECTS OF SOCIAL WORK ON REFINEMENT OF POVERTY RELIEF}

\section{A. Social work is able to answer the question of 'whom to help'}

It is a process of identifying really impoverished people. As President Xi Jin Ping says, poverty relief measures shall target those truly impoverished groups and shall avoid being none-sense. Currently, social workers need to intensify the process of poverty relief by pinpointing subjects and refining policies, so as to realize targeted relief of poverty, a mission that shall be based on refined works. Social workers shall be able to distinguish disadvantaged groups, analyze their difficulties, and identify poverty causes, so as to relieve poverty house by house and person by person. According to Chinese government’s guideline, farmers with yearly disposable income of lower than CN $¥ 2,300$ are classified as impoverished group. However, it is practically hard for village/county administrators to accurately calculate each farmer's income. Social workers, on the other hand, are advantaged to carry on this task through professional approaches and refined methods. They are able to analyze the farmers' family background, living environment, labor duration, paid efforts and other objective factors, and assess the farmers' feelings about poverty and their wills to get rid of it. Social workers are also able to identify factors that have caused and might continue to cause poverty, as well as factors that might help relieve such poverty. Social workers might design scales to measure degree of poverty, or carry out interviews to assess the subjects, thereby minimizing errors and mistakes.

\section{B. Social work is able to answer the question of 'who helps' by mobilizing social resources}

Currently, China's poverty relief project has entered a critical stage and started to target the most impoverished people. This group is the hardest to help out, but the country's goal of overall well-off will not be realized unless this group has been relieved from poverty. The country is about to secure poverty relief achievement, accelerating economic development, improving ecosystem, promote growth level, and narrow down regional differences. Unlike remedies or charity moves in other countries, China's poverty relief initiative is a political project. Social work is able to organize social resource and coordinate poverty alleviations to refine this mission. Social workers believe that people are interdependent with the society, and that assistance to the impoverished groups shall include cultivation of the subjects' capacity, improvement of the environment, and mobilization of social resources. Social work will help impoverished groups to solve problems and empower them to bear hardships, and will also provide them with social resources and improved environments.

\section{CONCLUSION}

In summary, social workers shall rely on their professionalism to improve their skills of poverty alleviation by precise identification of the impoverished people. The values, professionalism, scientific method and experiences that social workers carry are all resources for alleviation of poverty, which faces a number of challenges. This mission calls for purposeful action by the government, intentional participation by the farmers, appropriate anti-poverty measures, and exact outcomes. It aims at fine improvements of farmers' living conditions, and sharp changes of countryside environment. Social work is well positioned to fulfill such a task.

\section{REFERENCES}

[1] Amartya Sen, Poverty and Famines [M] Translated by Wang Yu, Beijing; The Commercial Press, 2009

[2] Ying Xing, Farmers, Organizations and the Nation-60 Years' Evolution of the Relation between Farmers and the Nation [M], Beijing; China Social Sciences Press, 2014:8-12

[3] Li Yingsheng Innovative Ways-Intervention of Social Work in Governance [J] Social Work and Management, 2014 (3):23-28

[4] Zhang Ming. Evolution of Social Power and Cultural Structures in Countryside: 1903-1953 [M] Xi'an:Sha’anxi People’s Publishing House, 2013:7

[5] He Xuefeng, China in the Process of Urbanization [M] Beijing: Orient Publishing Center, 2014: 235

[6] Yan Yunxiang. Individualization among Chinese Society [M].Translated by Lu Yang et al. Shanghai: Shanghai Translation Publishing House, 2016:305

[7] Zhang Yi, Social Governance: New Ideas and Practices [M] Beijing: Social Sciences Academic Press, 2014:100

[8] Ding Yuanzhu, Conflicts and Reconciliation: Social Relations amidst Offer of Public Services [M]. Beijing: Peking University Press 2015:5

[9] Wang Sibin Discussions on Domestic Social Work [J] Jiangsu Social Sciences, 2011(1):12-17

[10] XuXuanguo, Qi Yu, Zhou Xiaoyan, Theoretical Innovation of and Reflection on Intervention of Social Work in Rural Development-In Terms of Innovative Social Governance [J]. Journal of China Agricultural University (Social Sciences Edition), 2014(4):38-48

[11] Xiang Deping, Yao Xia Room for and Means of Intervention of Social Work in Anti-Poverty Measures [J] Teaching and Research, 2009(6):2226

[12] Huang Chengwei, 2015, Targeted Poverty Alleviation and Construction of National System of Poverty Alleviation [M] Journal of China Executive Leadership Academy, Yan’An. Vol. 1 